\title{
ESTIMATION OF OPTIMUM PLOT SIZE, NUMBER OF REPLICATIONS AND NUMBER OF SAMPLING UNITS FOR ASSESSMENT OF POWDERY MILDEW SEVERITY ON FLAX Abbas, Iman Kh. ${ }^{*}$ and M. R. Omar** ${ }^{*}$ Central .Lab., for Design \& Statistical Analysis Research, A.R.C. ${ }^{* *}$ Plant pathology Research Institute A.R.C.
}

\begin{abstract}
A two-field experiments was conducted at Tag El- Ezz Agricultural Research Station to evaluate the fungicides Cabrio Top and Amistar, applied as foliar sprays, for control of powdery mildew on six flax cultivars(Giza 9, Giza 10,Sakha 3, Sakha 4 ,Istro and Jetika) with varying levels of susceptibility to the disease. Disease severity (DS) was used as criterion for evaluating the performance of the tested fungicides. In the first season, the differences in DS between fungicides and the control was not the same for each cultivar, that is, cultivars responded differently to the application of fungicides. Amistar was more efficient than Cabrio Top in reducing DS on all the tested cultivars except Jetika where they showed almost the same level of efficiency. In the second season, the fungicides showed almost the same performance of the first season. Data were statistically analyses according to Smith (1938) and Lessman and Atkins (1963) to estimate optimum plot size, number of replications, and number of sampling units for assessment of powdery mildew severity. Results indicated that increasing plot size decreased the variance per basic unit, the index of soil variability ranged from 0.387 to 0.432 . The optimum plot size in Smith,s method was $2.560 \mathrm{~m}^{2}$ and in maximum curvature method was $1.895 \mathrm{~m} 2$. The standard error for the severity decreased as number of sample units increased. The optimum number of replications was 4-6 and the number of samples was 8-12. The required number of samples units to achieve the same level of precision with number of replications indicated increasing precision. When the area of the experimental site is limited, it is better to increase the number of sampling units. The results of the present study suggest that the optimum plot size for assessment of powdery mildew on flax should range from 1.895 to 2.560 $\mathrm{m}^{2}$ as this will improve the chance of homogeneous distribution of natural inoculums (conidia) on plants.
\end{abstract}

Keywords Flax, severity, fungicides, varieties, optimum plot size, number of replications and number of sampling units

\section{INTRODUCTION}

Powdery mildew, caused by Oidium Lini Skoric, is widely distributed and a destructive disease of flax (Linum usitatissimum L.) in Egypt. Flax is grown for both seeds and fibers in the Nile Delta, in particular, the northern governorates. This area is characterized by the prevalence of warm, wet weather during the late period of flax growing season. Such weather favors epiphytotic spread of the disease when virulent isolates of $O$. lini occurs (Mansour, 1998).

Currently, resistance to powdery mildew is not available in commercially grown flax cultivars in Egypt. Therefore, in years when environmental conditions favor the development of the disease, foliar application of fungicides has become the only commercially available 


\section{Abbas, Iman Kh. and M. R. Omar}

management practice for the disease control. These fungicides include sulpher and sterol biosynthesis inhibitors, such as Bayleton, Bayfidan, and Rubigan (Khalil et al.,1987, Aly et al., 1994, Mansour, 1998, Mansour, et al., 1999, and Aly et al., 2000).

A accurate assessment of plant disease severity, although critical to understanding the epidemiology of plant disease and yeald loss relationships, continues to be a major and often unresolved problem (Rouse et al., 1981). In the present study, disease severity (DS) was estimated visually as percentage of infected leaves / plant in a random sample of 10 plants/plot. Although this method involved objective judgment, it is tedious and timeconsuming. basic biometrical knowledge of the factors, which may affect the precision of (DS) must be obtained before (DS) can be used efficiently as a measure of disease intensity.

Sampling unit is the unit which measurement is made. The number of these units taken from each experimental unit is known as sample size. In a replicated field experiments where each experimental unit is a population, sample size may be the number of plants used for measuring the studied traits .The procedure. For selecting these plants is called the plot sampling technique.

In the analysis of variance of split- plot design, the magnitude of the fourth category is estimated by the residual error used to lose the significance of treatment effects. Where the residual variation is large, Standard errors may be reduced by having more replicates, but the replications required may be unacceptably costly, or increase in the number of samples per plot. Khalil et al (1970) found that, using smaller plots and more replications reduced both the standard error and coefficient of variability. Smith (1938) reported a linear relationship between the logarithm of the variance among plots of a given size and the logarithm of plot size. Galal and Abou El- Fittouh (1971) pointed out that the sensitivity of the experiment to detect differences of specified magnitude, between treatment means is affected to the same extent by either increasing number of replications or plot size.

Hanna (1972) indicated that increasing number of replications was more effective than increasing plot size. Hach (1976) reported that, the increases in precision is obtainable by varying the number of plants sampled per treatment, are considered in relation to their costs. Excessive replication would be required to establish differences of interest. Attention should be given to sources of error variation when such large errors are found. Ismail et al (1982)

To develop a plot sampling technique for the measurement of a character in a given trial, the researcher must clearly specify the sampling unit, the sample size, and the sampling design (Gomez and Gomez) 1984. They also stated that the required sample size is governed by size of variability among sampling units within the same plot and by the degree of precision desired to be detected.

Lefoet (1987) stated that, in field experimentation, the efficiency of comparison between treatments depends on the precision of the experimental design. This precision is particularly linked to the size and number of experimental units. The optimum number of experimental units is 
strongly dependent on the land characteristics as well as on the nature of measured variable, and on expected error variance.

Nasr and Leilah (1993) reported that the standard error decreased as number of sample units or replications increased. Salm and Salama (2001) reported that the standard error decreased as number of sample units or replications increased.

The objective of the present study was to estimate optimum plot size, number of replication, and number of sampling units for assessment of powdery mildew severity on flax after foliar application of fungicides. Efficiency of fungicides in controlling powdery mildew was also evaluated.

\section{MATERIALS AND METHODS}

\section{1-Field Procedure:}

Experiments were conducted over two successive growing seasons at Tag El-Ezz Agricultural Research Station, beginning in the fall of 2010. Experiments consisted of a split- plot design of three replications. Plots were $2 \times 3 \mathrm{~m}\left(6 \mathrm{~m}^{2}\right)$ and consisted of 20 rows spaced $10 \mathrm{~cm}$ apart. Main plots were manually planted with the tested cultivars (Table 1) at a rate of $50 \mathrm{~kg} / \mathrm{feddan}$ on 18 November 2010 and on 23 November 2011.All the agricultural practices for growing flax were conducted according to the recommendations.

Table 1. Origin, type, and pedigree of flax cultivars used in the present study.

\begin{tabular}{|lllll|}
\hline No & Cultivar & Origin & Type & Pedigree \\
\hline 1 & Giza 9 & Local cultivar & Fiber & L. 420 x Bombay \\
2 & Giza 10 & Local cultivar & Fiber & L. 420 x Bombay \\
3 & Sakha 3 & Local cultivar & Fiber & Bleinka (2E) x 1.2096 \\
4 & Sakha 4 & Local cultivar & Fiber & Bleinka (R3) x 1.2096 \\
5 & Istro & Introduced from Romania & Fiber & Unidentified \\
6 & Jiteka & Introduced from Czech & Fiber & Unidentified \\
\hline
\end{tabular}

Powdery mildew was allowed to develop naturally, and the initial fungicide application to cultivars coincided with the first sign of the disease. Foliar sprays were applied to sub- plots at the recommended rates (Table 2) on 12 and 26 April 2010 and on 27 April and 12 May 2011. DS (Nutter et al.,1991) was rated visually on 13 May 2010 and on 28 May 2011.

DS was measured as percentage of infected leaves/plant in a random sample of 10 plants/plot. Fungicidal efficiency was calculated based on DS according to the following formula (DSC-DSF)/ DSC) $\times 100$, where DSC is disease severity of the control and DSF is disease severity of fungicide. 
Table 2. Fungicides used for control of powdery mildew of flax under field conditions in Tag El- Ezz in 2010/2011 and 2011/2012 growing seasons.

\begin{tabular}{|lclc|}
\hline Fungicide $^{\text {a }}$ & $\begin{array}{c}\text { Rate per100 liters } \\
\text { of water }\end{array}$ & \multicolumn{1}{c|}{ Active ingradient $^{\mathbf{b}}$} & Formulation $^{\mathbf{c}}$ \\
\hline Cabrio Top & $100 \mathrm{~g}$ & $5 \%$ Pyraclostrobin+55\% Metiram & WG \\
Amistar & $50 \mathrm{ml}$ & $25 \%$ Azoxistrobin & SC \\
\hline
\end{tabular}

$a=$ Trade name

$\mathrm{b}=$ Common name

C= Formulations were wettable granules (WG) or soluble concentrate (SC).

\section{2- Statistical analysis procedures:}

\subsection{Optimum plot size:}

Soil heterogeneity index

The procedure (reported by Gomez and Gomez, 1984) involves the use of the basic analysis of variance to estimate the variance for plots of different sizes, and the use of these estimates to drive a relationship between plot variance and plot size. The number of plot

variances that can be estimated through this procedure is only as many as the number of plot sizes available in the design used.

The steps of procedure were as follows:

1- The basic formats for the analysis of variance for a split-plot design with sampling error are shown in (Table 3).

Table 3 Analysis of variance for a split plot design.

\begin{tabular}{|c|c|c|c|}
\hline $\begin{array}{l}\text { Source of } \\
\text { variance }\end{array}$ & $\begin{array}{l}\text { Degree of } \\
\text { freedom }\end{array}$ & $\begin{array}{l}\text { Mean } \\
\text { square }\end{array}$ & $\begin{array}{l}\text { Variance between plots of various } \\
\text { sizes }\end{array}$ \\
\hline Replications & $r-1$ & M1 & \multirow[t]{2}{*}{$\mathrm{V} 1=\mathrm{m} 1$} \\
\hline Factor a & a-1 & & \\
\hline & & & \multirow{4}{*}{$V 2=\frac{R(t-1) M 2+(r-1) M 1}{r t-1}$} \\
\hline Error (a) & $(r-1)(b-1)$ & M2 & \\
\hline Factor b & $b-1$ & & \\
\hline AXB & $(a-1)(b-1)$ & & \\
\hline Error (b) & $a(r-1)(b-1)$ & M3 & \multirow{2}{*}{$V 3=\frac{\operatorname{Tr}(s-1) M 3+r(t-1) M 2+(r-1) M 1}{r t s-1}$} \\
\hline Total & rab-1 & & \\
\hline
\end{tabular}

2- Compute estimates of the variances associated with the different plot sizes, following the formulas given in (Table 3). In this study, the design is split plot design, there are three between plot variances corresponding to the three variances between plots corresponding to the three variances between plots corresponding to the three plot sizes as follow:

$\mathrm{V} 1=$ the variances between plots of the block size.

$\mathrm{V} 2=$ the variances between plots of the main plot size.

$\mathrm{V} 3=$ the variances between plots of the sub plot size.

The Computation of these of variances was based on the mean square value in the analysis of variance. 
3- For each variance estimate $\mathrm{Vi}$ obtained in step2, compute the corresponding comparable variance Vi with the size of the smallest plot in the particular experiment as the base:

$\mathrm{Vi}=\mathrm{Vi} / \mathrm{Xi}$

Where: $X$ is the size of the its plot in terms of the smallest plot involve.

4- Apply the appropriate regression technique to estimate the regression coefficient (b). (The index of soil heterogeneity): from the equation:

$$
\log \mathrm{Vi}=\log \mathrm{V} 3-\mathrm{b} \log \mathrm{X} \text {. }
$$

Where $\mathrm{Vi}$ and $\mathrm{Xi}$ are defined in step3

\section{5- Optimum plot size (X opt.)}

The weight index of soil variability, was Calculated ignoring cost factors, the optimum plot size (Xopt.) was determined, using The method developed by smith (1938), by the equation: Xopt. $=b /(1-b)$

The exponential relationship between the coefficients of the variability (C.V.) and plot size (X),

C. $V .=A X^{-B}$, was transformed into the logarithmic form:

$\log C . V=\log A-B \log X$

Where $A$ and $B$ are the $Y$ - intercept (constant of the equation) and regression Coefficient, respectively. The values of $A$ and $B$ in the above equation were estimated from the values of C.V. of replications and two experimental errors to determine the point of maximum Curvature ( $C$ max). The values of $A$ and $B$ were substituted in following formula which was developed

Galal and Abou El-Fittouh (1971).

$$
C \max =\left(A^{2} B 2(2 B+1) /(B+2)\right)^{1 /(2 B+2)}
$$

The point of maximum curvature indicates a critical value of the optimum plot size.

\section{6- Convenient number of replications and sample size}

The statistical model for the design is:

$$
Y i j k=U+B i+T j+B T+E i j+S i j k
$$

Where: $i=1,2$ , (treatments) $, j=1,2$ (sampling units),

$\mathrm{Bi}=$ blocks effect, $\mathrm{Eij}=$ random experimental error,

Sijk = random sampling error and $U=$ mean.

\section{The steps of procedure were as follows:}

1- From estimating of the experimental error and sampling error

$$
\text { S1 } 2=M 3 \quad \text { S2 } 2=(M 2-M 3) / n
$$

Where: $\mathrm{M} 3$ is the sampling error mean square, M2 is the experimental error mean square in the analysis of variance and $n$ is the sample size in field experiment.

2- Compute the estimates of the variance of strips mean and the corresponding coefficient of variability value as:

$\mathrm{V}(\mathrm{x}-)=(\mathrm{S} 22+\mathrm{nS} 12) / \mathrm{r} \mathrm{n}$

CV $(x-)=(100 * \operatorname{SQR}(\mathrm{V}(\mathrm{x}-)) / \mathrm{x}-$

Where $r$ is the number of replications, $x$ - is the grand mean of the character.

3- Repeating this process by increasing the number of replications ( $r$ ) or the sample size $(n)$ to reach the convenient degree of precision. Two, four, 
six replications were used as the economical number of samples $(\mathrm{N}=$ $2,4, \ldots ., 12$ plants ).

4- The convenient numbers of sampling units for each number of replication were determined by the point of maximum curvature (C max) for exponential equation between the coefficient of variability (C.V.) and sample units.

$$
\text { C.V. }=A * X^{B}
$$

Where $A$ is $Y$ intercept and $B$ is the regression coefficient.

\section{RESULTS AND DISCUSSION}

\section{Analysis of variance of powdery mildew severity (PMS).}

ANOVA (Table 4) showed that cultivar, fungicide, and their interaction were all highly significant $(P=0.000)$ sources of variation in PMS in both seasons. However, fungicides were always the most important source of variation as they accounted for 89.14 and $91.24 \%$ of the explained variation in the first and second seasons, respectively. Cultivars were the second in importance, while the interaction was the least important source of variation.

Table 4 Analysis of variance of effect of flax cultivars, fungicides, and their interaction on severity of powdery mildew.

\begin{tabular}{|c|c|c|c|c|c|c|c|c|c|}
\hline \multirow[b]{2}{*}{$\begin{array}{l}\text { Source of } \\
\text { variance }\end{array}$} & \multirow[b]{2}{*}{ 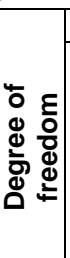 } & \multicolumn{4}{|c|}{ 2010-2011season } & \multicolumn{4}{|c|}{ 2011-2012 season } \\
\hline & & $\begin{array}{l}\text { Mean } \\
\text { square }\end{array}$ & F-value & Sig & 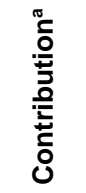 & $\begin{array}{l}\text { Mean } \\
\text { square }\end{array}$ & F-value & Sig & $\begin{array}{l}\text { 을 } \\
\text { 을 } \\
\text { 은 } \\
\text { 등 }\end{array}$ \\
\hline Replications & 2 & 5.708 & 0.796 & 0.478 & & 3.22 & 0.340 & 0.720 & \\
\hline Cultivars (C) & 5 & 590.175 & 82.310 & 0.000 & 6.05 & 435.862 & 46.023 & 0.000 & 4.77 \\
\hline Error (a) & 10 & 7.170 & 1.272 & 0.300 & & 9.470 & 1.707 & 0.137 & \\
\hline Fungicides(F) & 2 & 21748.711 & 3857.608 & 0.000 & 89.14 & 20833.628 & 3754.848 & 0.000 & 91.24 \\
\hline CXF & 10 & 97.332 & 17.264 & 0.000 & 4.79 & 75.546 & 13.616 & 0.000 & 3.90 \\
\hline Error & 24 & 5.638 & & & & 5.548 & & & \\
\hline Total & 53 & & & & & & & & \\
\hline
\end{tabular}

${ }^{a}$ Relative contribution to variation in powdery mildew severity, calculated as percentage of sum of squares of the explained (model) variation.

Due to the very highly significant interaction between cultivars and fungicides $(P=0.000)$, an interaction least significant difference (LSD) was calculated to compare fungicidal means within each cultivar (Table 5). The comparison showed that the differences in DS between fungicides and the control was not the same for each cultivar, that is, cultivars responded differently to the application of fungicides. For example, in the first season, Cabrio Top reduced DS by 47.85 and $74.81 \%$ on Giza10 and Sakha 4, respectively, that is, Giza10 was the least responsive cultivar to the application of Cabrio Top, while Sakha 4 was the most responsive cultivar. On the other hand, Amistar reduced DS by 57.43 and $85.04 \%$ on Jetika and Istro, respectively that is, Jetika was the least responsive cultivar to the 
application of Amistar while Istro was the most responsive one. Amistar was more efficient than Cabrio Top in reducing DS on all the tested cultivars except Jetika where they showed almost the same level of efficiency. In the second season, the fungicides showed almost the same performance of the first season (Table 5).

The effect of cultivar on efficiency of fungicides in controlling powdery mildew of flax, as we have demonstrated herein, has been previously reported by Aly et al.(2000). These results suggest that efficiency of fungicides in controlling flax powdery mildew should be evaluated by using as many cultivars as possible as this will improve the chance of identifying fungicides effective in controlling the disease on many cultivars.

\section{The optimum plot size for flax plant}

The results of basic format of the analysis of variance for a split- plot design are shown in Table 4 To determine the difference among mean squares between replications and experimental errors, variance ratios $(F)$ were calculated by dividing mean squares of replications, error (a) and error (b), these values were compared with the tabulated $(F)$ value at the corresponding degrees of freedom. The result given in Table (4) indicated that there is significant difference in most of the cases, for the two seasons, showing the effect of plot shape. This however was expected. They affect the experimental design and both size of plot and number of replications therefore, the variance was increased, when the plot size increased.

\section{1- Soil variability index}

The weighted index of soil variability, b, was found to be 0.387 and 0.432 for the two seasons 2010-2011 and 2011-2012. These results indicated that soil heterogeneity was intermediate in the fields.

\section{2- Optimum plot size}

Results presented in Table 6 indicated that plot variance reduced due to increment in plot size, and coefficient of variability (C.V.) reduced when number of plots increased. However, this reduction is not in proportion with the increase in the size of plots, the rate of reduction decreases as the plots became larger this confirms the fact that the relationship between plot size and coefficient of variability is exponential in nature.

The coefficient of variability decreased rapidly at first in the two seasons and then decreased slowly as plot size increased (Fig.1 and 2).This relation was similar to that previously reported by all investigators studying the same problem.

The equation describing this relationship has the general form:

C. $\mathrm{V}=A X^{-B}$ 
Abbas, Iman Kh. and M. R. Omar

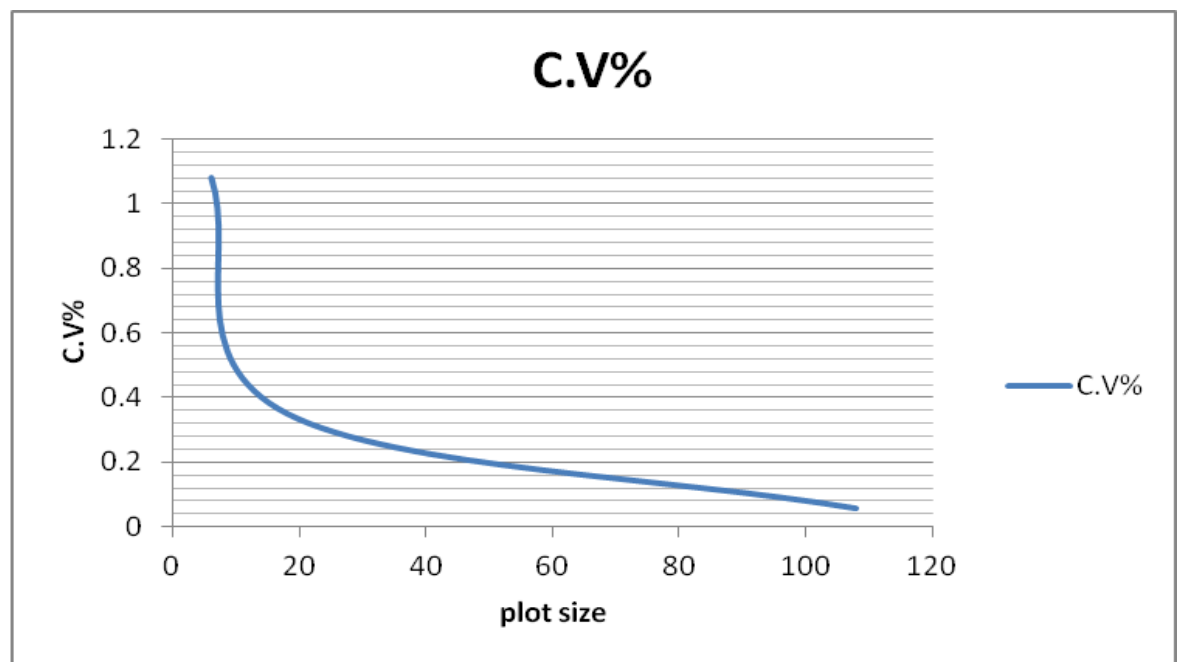

Fig 1.Relationship between plot size and coefficient of variability (C.V.) for flax severity in season $\mathbf{2 0 1 0 - 2 0 1 1}$

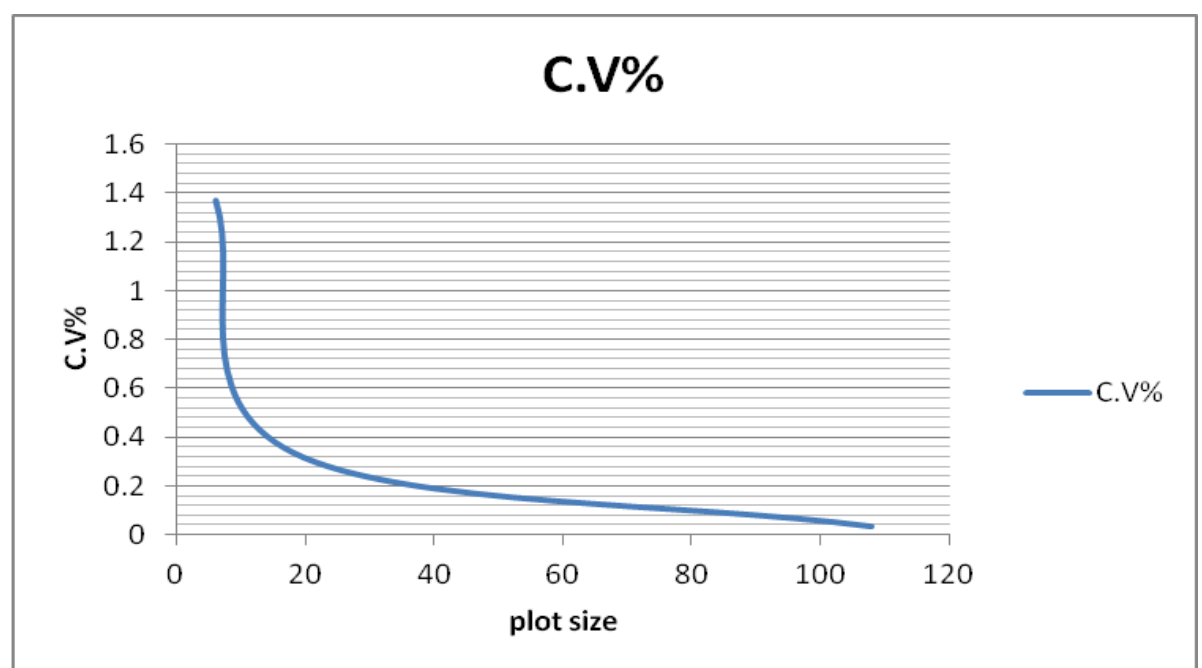

Fig 2.Relationship between plot size and coefficient of variability (C.V.) for flax severity in season 2011-2012 
Table 5 Effect of flax cultivar, fungicide, and their interaction on severity of powdery mildew.

\begin{tabular}{|c|c|c|c|c|c|c|c|c|}
\hline \multirow[b]{3}{*}{ Cultivars } & \multicolumn{4}{|c|}{ 2010-2011season } & \multicolumn{4}{|c|}{ 2011-2012 season } \\
\hline & \multicolumn{3}{|c|}{ Fungicides } & \multirow[b]{2}{*}{ Mean } & \multicolumn{3}{|c|}{ Fungicides } & \multirow[b]{2}{*}{ Mean } \\
\hline & Control & $\begin{array}{c}\text { Cabrio } \\
\text { Top }\end{array}$ & Amistar & & Control & $\begin{array}{c}\text { Cabrio } \\
\text { Top }\end{array}$ & Amistar & \\
\hline Giza 9 & 91.32 & 31.12 & 23.72 & 44.68 & 88.40 & 30.74 & 24.90 & 48.01 \\
\hline Giza 10 & 79.27 & 41.34 & 24.93 & 48.51 & 78.94 & 35.51 & 23.06 & 46.84 \\
\hline Sakha 3 & 94.35 & 31.38 & 20.05 & 48.59 & 92.84 & 30.97 & 21.70 & 48.50 \\
\hline Sakha 4 & 74.68 & 18.81 & 14.66 & 36.05 & 72.63 & 20.63 & 15.53 & 36.26 \\
\hline Istro & 83.21 & 24.57 & 12.45 & 40.08 & 83.00 & 22.27 & 13.94 & 39.74 \\
\hline Jetika & 97.65 & 38.82 & 41.57 & 59.35 & 93.93 & 35.10 & 38.53 & 55.85 \\
\hline Mean & 86.75 & 31.01 & 22.90 & & 84.96 & 29.20 & 22.94 & \\
\hline
\end{tabular}

L.S.D for cultivar $x$ fungicide interaction $=5.42(p \leq 0.001)$

$=5.38(p \leq 0.001)$

$=3.99(\mathrm{p} \leq 0.005$

$=3.96(p \leq 0.005)$

The values of $A$ and $B$ were estimated and found to be $0.835,-1.029$ for the first season and 1.129, -1.275 for the second season.

Therefore, the equations were defined as:

$$
\begin{aligned}
& \text { C. } V=0.835 \quad X^{-1.029} \\
& \text { C.V }=1.129 \quad X^{-1.275}
\end{aligned}
$$

Table 6. Variance and coefficient of variability (C.V)of different plot sizes

\begin{tabular}{|c|c|c|c|c|c|c|c|c|}
\hline \multicolumn{6}{|c|}{$2010-2011$} & \multicolumn{3}{|c|}{ 2011-2012 } \\
\hline 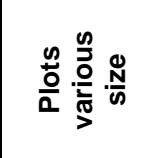 & 흠 $\frac{\text { ลั }}{\frac{N}{\omega}}$ & $\begin{array}{l}\frac{0}{0} \\
\frac{0}{2} \\
\overleftarrow{0} \\
\dot{0} \\
z\end{array}$ & 흔 $\frac{d}{\frac{0}{\pi}}$ & 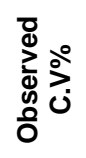 & 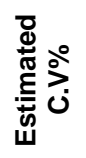 & 흠 $\frac{\stackrel{0}{\frac{0}{\pi}}}{\frac{\pi}{\frac{\pi}{J}}}$ & 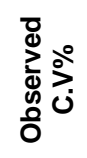 & 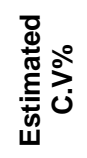 \\
\hline Replication & 108 & 18 & 0.053 & 5.096 & 0.055 & 0.030 & 3.912 & 0.035 \\
\hline Main plot & 18 & 6 & 0.389 & 5.712 & 0.350 & 0.485 & 6.709 & 0.338 \\
\hline Sub plot & 6 & 1 & 1.012 & 5.065 & 1.082 & 1.095 & 5.135 & 1.370 \\
\hline
\end{tabular}
for flax in 2010-2011 and 2011- 2012 seasons.

The optimum plot size was calculated by the two following methods 1-Smith's methods : (Smith ,1938)

The results indicated that the optimum plot size was $2.319 \mathrm{~m}^{2}$ in the first season and $2.592 \mathrm{~m}^{2}$ in the second season. (Table 7)

\section{Maximum curvature method Lessman and Atkins,1963)}

According to the modified maximum curvature procedure ,the optimum plot size was $1.107 \mathrm{~m}^{2}$ in the first season and $2.682 \mathrm{~m}^{2}$ in the second season .(Table 7)

The index of soil variability, b, was 0.387 in 2010-2011 season and 0.432 in 2011-2012 season. Theoretically, the index varies between zero and one. In the two trails, the $b$ values indicate that an intermediate degree of correlation is present.

Using the obtained value of $b$ in computing the optimum plot size for the two trails, It should be noted that smith (1938) pointed out that areas half or double the optimum plot size would be $96 \%$ as efficient as the optimum 
plot size $m$ when $b=0.5$, The mean of optimum plot size over all two seasons was $2.560 \mathrm{~m} 2$ by using smith procedure.

Table 7. Optimum plot size for flax calculated by Smith's and maximum curvature methods

\begin{tabular}{|c|c|c|c|c|c|}
\hline \multicolumn{3}{|c|}{ Smith's method } & \multicolumn{3}{|c|}{ Maximum curvature method } \\
\hline \multicolumn{6}{|c|}{ Optimum plot size } \\
\hline Season & b & Area $/ \mathrm{m}^{2}$ & $\mathbf{A}$ & B & Area $/ \mathrm{m}^{2}$ \\
\hline 2010-2011 & 0.387 & 2.319 & 0.835 & -1.029 & 1.107 \\
\hline 2011-2012 & 0.432 & 2.592 & 1.129 & -1.275 & 2.682 \\
\hline Mean & & 2.560 & & & 1.895 \\
\hline
\end{tabular}

Applying the maximum curvature method, the optimum plot size, was calculated in the two seasons with mean $1.895 \mathrm{~m}^{2}$.

The results of applying the two methods of determining the optimum plot size different. Smith $s$ method result is larger than the maximum curvature method for the two seasons.

\section{Convenient number of replication and sample units}

Data presented in (Table 8) and (figures 3 and 4 ) show the values of standard error for various combinations of number of replications and number of samples in seasons 2010-2011 and 2011-2012.

Data revealed that the required number of samples units to achieve the same level of precision with four and six replications was relatively low if compared with those required with two and four replications. This indicated that, increasing number of replications more than four had no high improvement in the degree of precision, but when the amount of lands is not available, it is better to increase the number of sample unit. These results are in agreement with these reported by Lefoet (1987).

Increasing number of samples or replication decreased the values of standard error (fig. 3 and 4) However, increasing number of samples was proportional to the increase in number of replications.

Table 8. Estimated standard error for different combinations of samples size and number of replication for flax severity.

\begin{tabular}{|cccccccc|}
\hline \multicolumn{2}{|c|}{ No.of replication } & \multicolumn{7}{|c|}{ No. of samples } \\
\hline \multirow{2}{*}{$\begin{array}{c}\text { First } \\
\text { season }\end{array}$} & 2 & 365.66 & 204.37 & 150.61 & 123.72 & 107.60 & 96.84 \\
\cline { 2 - 8 } & 4 & 218.83 & 102.18 & 75.30 & 61.85 & 53.78 & 48.42 \\
\cline { 2 - 8 } & 6 & 121.89 & 68.12 & 50.20 & 41.24 & 35.86 & 32.28 \\
\hline \multirow{2}{*}{$\begin{array}{c}\text { Second } \\
\text { season }\end{array}$} & 2 & 277.54 & 156.31 & 115.90 & 95.70 & 83.57 & 75.49 \\
\cline { 2 - 8 } & 4 & 138.77 & 78.16 & 57.95 & 47.85 & 41.78 & 37.74 \\
\hline
\end{tabular}


J. Plant Production, Mansoura Univ., Vol. 4 (10), October, 2013

Fig 3. Relation between number of replication and number of samples in season 2010-2011

Fig 4. Relation between number of replication and number of samples in season 2011-2012 


\section{REFERENCES}

Aly, A.A., A.Z.A Ashour, E.A.F E-Kady, and M.A. Mostafa. (1994). Effectiveness of fungicides for control of powdery mildew of flax and effect of the disease on yield and yield components. J. Agri. Sci. Mansoura Univ., 19 : 4383-4393.

Aly, A.A., M.T.M. Mansour, M.S.A. Felaifel, S.M.E. Zayed, and A.M. ElKafrawy, (2000). Use of fungicides, bicarbonate salts, and filmforming polymers to supress powdery mildew of flax. J. Agric. Sci. Mansoura Univ. 25: 6131-6151.

Federer, W.T. (1955). Experimental Designs. McMillan Co., New York.

Galal ,H.E and H.A Abou - El-Fittoh (1971) :Estimation of optimum plot size and shape for Egyption cotton yield trials .Alexandria J. Agric .Res.19:233-238 .

Gomez ,K.A.and A.A.Gomez (1984):statistical procedures for Agriculture research .2and edition .John Wiley and sons ,inc. New York.

Hach H.R.B.(1976):components of error in field experiments with cotton ,groundnuts ,Kenaf and sesame in the central sudan rainlands 1.Field and stastical, methods increasing precision by relocation and its cost ,Exp.Argic.12(3): 209-244.

Hanna,L.i.(1972):Estimation of soll variability and convenient plot size from field experiments .M.Sc thesis, instit. Of stat studies and Res, Cairo univ,Egypt.

Ismail M.H.;M.G.Thane; i.h.louis and A.R.mohamed (1982). Estimation of convenient plot size and number of replications for some egyption varieties.11 th international congress for stastical, computer science, social and demographic Research. Cairo Egypt. 29 March -3April. 239-254.

Khalil,M.S.,B.A. Yossef, H.A. Eisa, and Afaf A. Amr. (1987). Status of varietal reaction and chemical control of flax powdery mildew caused by Oidium lini. pp. 347-358. In: Proc. 5th Congr. Egypt. Phytopathol. Soc., Giza.

Khalil, A.R.; S.E.El kalla and A.M.Kasdy (1970). Optimum plot size and shape in field trials 1 -cotton . proc. Of the $6^{\text {th }}$ stst. Conf.inst.of stst.students and res., Cairo univ., 1:66-80.

Lessman, K.J.and R.E. Atkins (1963): Optimum plot size and relative efficiency of lattice designs for grain sorghum tests .Crop sci. 3: 477481.

Lefoet,p.l.(1987). Some fundamental aspects of experimentation on perennial fruit plants. Sixiem,e colloque sur les recherché fruitueres, Dec.,21-28

Mansour, M.T.M. 1998. Pathological studies on powdery mildew of flax in A.R.E.Ph.D. Thesis, Zagazig Univ., Moshtohor, 148 p.

Mansour, M.T.M., A.A. Aly, S.M.E. Zayed, and M.A. Mostafa . (1999). Effectiveness of seed treatments and foliar fungicides for control of powdery mildew of flax cultivars. J. Agric. Sci. Mansoura Univ., 24: 5497-5508. 
Nasr, S.M. and A.A. Leilah ( 1993). The balance between sample size and number of replication to increase the precision of flax field experiments. Bull Fac. of Agric. Univ. of Cairo, vol. 44,No. 2 (1993): 347- 360 .

Nutter, F.W., Jr. P.S. Teng, and F.M. Shoks. (1991). Disease assessment terms and concept. Plant Dis. 75: 1187-1188. powdery mildew of flax. J. Agric. Sci. Mansoura Univ. 25: 6131-6151.

Rouse, D.I., D.R. Mackenzie, R.R. Nelson, and V.J. Elliott. (1981). Distribution of wheat powdery mildew incidence in field plots and relationship to disease severity. Phytopathology 71: 1015-1020.

Salm, M.M and S.M. Salama (2001). Estimation of optimum plot size, number of replications and convenient number of sample units in wheat yield trails. J. Agric. Sci. Mansoura Univ., 26(8): 4681-4696.

Smith, H.F.(1938). An empirical law describing heterogeneity in yields of agricultural crops. J. Agric. Sci., 28:1-23.

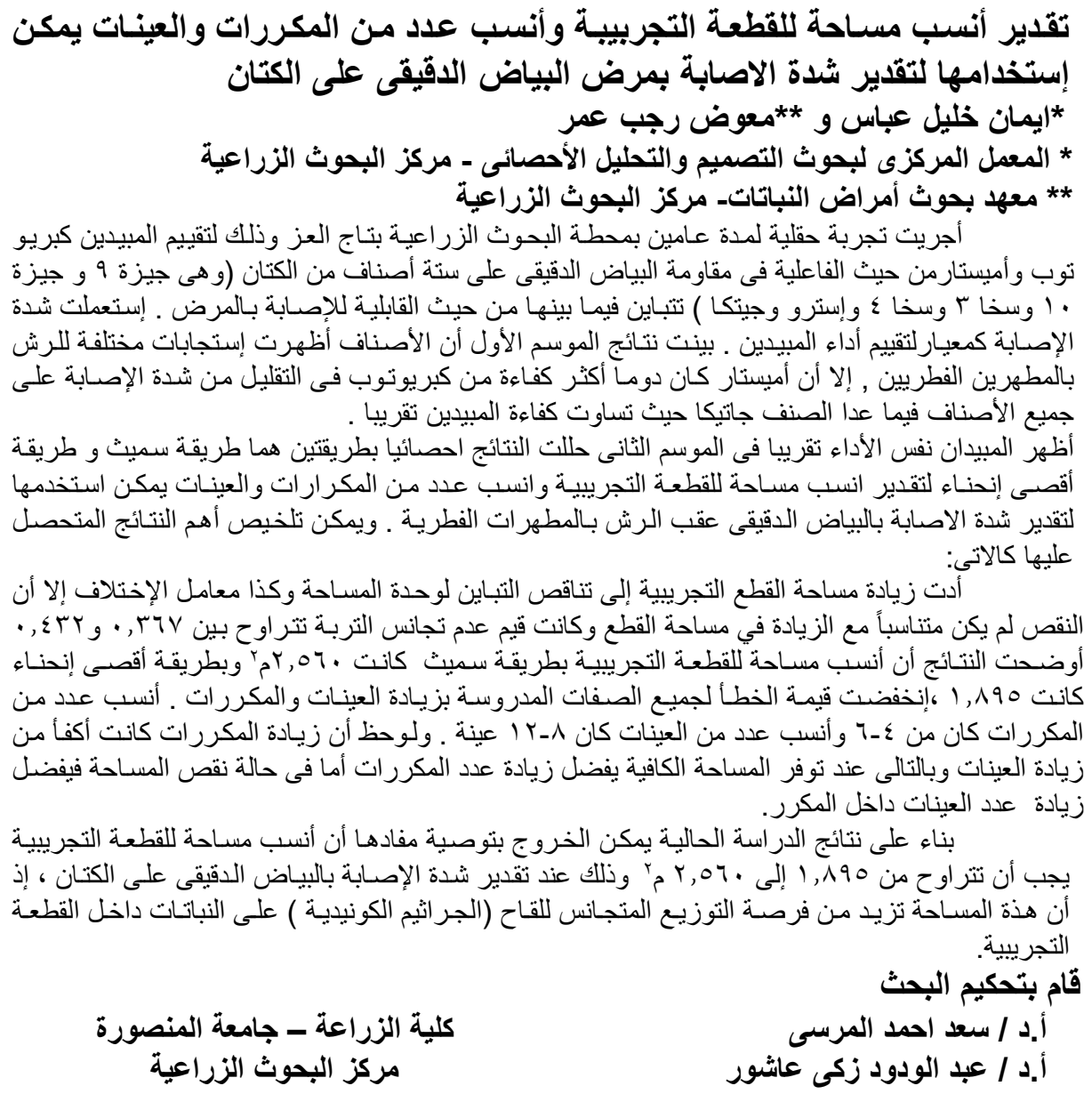


Abbas, Iman Kh. and M. R. Omar

1514 